\title{
VACINAS CONTRA O DENGUE
}

\author{
DENGUE VACCINES
}

Luiz Tadeu M. Figueiredo

Docente do Departamento de Clínica Médica, Faculdade de Medicina de Ribeirão Preto, Universidade de São Paulo. Luiz Tadeu M. Figueiredo - Unidade Multidepartamental de Pesquisa em Virologia - Faculdade de Medicina de Ribeirão Preto Campus da USP - 14049-900, Ribeirão Preto - SP - Brasil - E-mail: Itmfigue@fmrp.usp.br

FIGUEIREDO LTM. Vacinas contra o dengue. Medicina, Ribeirão Preto, 32: 21-25, jan./mar. 1999.

RESUMO: O controle do dengue é feito, nos dias atuais, em todo o mundo, seguindo normas de combate aos mosquitos vetores preconizadas por sanitaristas do começo do século. O controle e a erradicação do Aedes aegypti, vetor do dengue, é bastante difícil e necessita de grandes investimentos com funcionários, máquinas, venenos e campanhas educacionais permanentes. A alternativa ideal para o controle do dengue seria através do uso de vacinas. Neste trabalho de revisão, analisam-se pesquisas para o desenvolvimento de vacinas contra dengue, incluindo: as de vírus vivo atenuado; as de engenharia genética (vacinas recombinantes) tendo abordagens relativas à expressão de proteínas de dengue em células eucarióticas, aos vírus recombinantes, aos vírus mutantes ou quiméricos, e às vacinas com vetores vivos. Ainda, abordam-se as vacinas de DNA. Observa-se que as vacinas de vírus vivo e atenuado são aquelas que têm as melhores perspectivas para serem utilizadas de forma generalizada, no controle do dengue, dentro de alguns anos.

UNITERMOS: Vacinas. Dengue.

O dengue é um problema mundial de saúde pública. Trata-se da mais importante arbovirose que afeta o homem. Estima-se que ocorram cem (100) milhões de infecções por dengue anualmente, ocasionando milhões de casos de doença febril e duzentos e cinqüenta mil (250 000) casos de dengue hemorrágico ${ }^{(1)}$. No Brasil, onde vêm circulando os tipos 1 e 2, iniciaramse as epidemias em 1986 e, atualmente, o dengue ocorre em todas as regiões do país, com dezenas de milhares de casos notificados anualmente, alguns com manifestações hemorrágicas e fatais ${ }^{(2)}$.

O controle do dengue é feito, nos dias atuais, em todo o mundo, seguindo as normas gerais de combate aos mosquitos vetores preconizadas pelos médicos sanitaristas do começo do século ${ }^{(3)}$. O controle e a erradicação do mosquito Aedes aegypti, vetor do dengue, é procedimento bastante difícil, que necessita de grandes investimentos com funcionários, máquinas, venenos e campanhas educacionais, permanentes, que mobilizem toda a comunidade ${ }^{(4)}$. Reconhece-se que a alternativa ideal para o controle do dengue seria através do uso de vacinas. Corroboram esse reconhecimento as vacinas existentes para outros flavivirus, pertencentes ao mesmo gênero dos vírus do dengue, como o da febre amarela, com excelente capacidade imunizante $^{(5)}$.

O desenvolvimento de uma vacina de dengue para uso em larga escala é considerada prioritária pela $\mathrm{OMS}^{(5)}$. Entretanto, o desenvolvimento dessa vacina tem frustrado a comunidade científica, devido a certas exigências e a problemas, tais como: a necessidade de a vacina imunizar contra os quatro (4) tipos de dengue, com alta eficiência, para evitar o mecanismo fisiopatológico que desencadeia o dengue hemorrágico; 
a inexistência de um modelo experimental e confiável para estudar a resposta pós-vacinal, o que ainda é feito por testes muito artificiais, como aqueles que utilizam camundongos inoculados pela via intracerebral ${ }^{(6)}$.

Os vírus do dengue, como os outros Flavivirus, são RNA vírus com genoma de polaridade positiva, possuindo dez (10) genes que se apresentam na seguinte ordem:

5'-C-PreM-E-NS1-ns2a-ns2b-NS3-ns4a-ns4b-NS5-3'. Os genes estão contidos em uma open reading frame que tem início em um resíduo de metionina e vai até a base 10158 ou 10302, dependendo do vírus. Resulta da tradução da open reading frame, uma poliproteína que libera, após clivagens, três (3) proteínas estruturais (E, M e C) e sete (7) não estruturais (NS1, NS2a e NS2b, NS3, NS4a e NS4b, e NS5) ${ }^{(7)}$. A proteína E, PM 53KD, a maior proteína viral, é glicosilada, possui vinte (20) resíduos conservados de cisteína, os quais formam seis (6) pontes dissulfídicas, e contém importantes determinantes antigênicos. Os anticorpos, principalmente os que se ligam a epítopos da proteína $\mathrm{E}$, promovem lise do envelope ou bloqueio de seus receptores, com conseqüente neutralização viral. A proteína $\mathrm{E}$, localizada nas espículas do envelope dos vírus do dengue é fundamental para a ligação viral ao receptor de membrana e possui os mais importantes domínios antigênicos destes microorganismos.Os epítopos de E definem a produção de anticorpos específicos para o tipo viral e para o gênero dengue. Podem ser detectados por múltiplos testes sorológicos (ensaios imunoenzimáticos e de imunofluorescência; testes de neutralização, de inibição da hemaglutinação e de facilitação da infectividade $)^{(7)}$. A estrutura tridimensional da proteína $\mathrm{E}$ consiste num complexo dimérico com duas subunidades idênticas. E é subdividida em três regiões distintas: I, região central da molécula, contendo o radical amina terminal; II, contém a maior parte dos contatos do dímero; III, inclui o $\mathrm{C}$ terminal e tem relação com a virulência de determinadas cepas virais. Os dímeros da proteína E quando expostos a pH ácido ( $\mathrm{pH}<6,5)$, sofrem uma transformação conformacional, sendo rearranjados em trímeros. Após a ligação viral ao receptor de membrana e a entrada da partícula no citoplasma por pinocitose, a conformação em trímeros de E seria fundamental para o processo de fusão do envelope viral com a membrana endossômica ${ }^{(8,9)}$. Os anticorpos contra E são dirigidos a epítopos existentes em toda a superfície externa da molécula. Os anticorpos neutralizantes relacionam-se à específica conformação do epítopo de $\mathrm{E}$, nas regiões I e II, para um determinado vírus. O mecanismo de neutralização relaciona-se à dissociação do dímero E pela presença do anticorpo, impedindo as alterações conformacionais que levam à formação dos trímeros da molécula. A neutralização, também, pode ocorrer com anticorpos ligados à região III, obstruindo o sítio de ligação viral ao receptor de membrana celular ${ }^{(8,9)}$.

Anticorpos, produzidos contra NS1, promovem lise viral, fixando o complemento. A NS1, com $40 \mathrm{KDa}$, possui atividade na maturação viral e é encontrada na superfície, ligada `a membrana da célula infectada, sendo, também, secretada ${ }^{(7)}$. A imunização com NS1 é capaz de proteger camundongos da encefalite, após serem inoculados com vírus do dengue ${ }^{(10)}$. Entretanto, o mecanismo de proteção, conferido pelas NS1, não é neutralizante das partículas virais e relaciona-se à destruição das células infectadas previamente à liberação da progênie viral ${ }^{(6,11)}$. Esses anticorpos atuam como mediadores de fenômenos de citotoxidade por linfócitos, através de seus receptores para a porção $\mathrm{Fc}$ de imunoglobulinas. Também, possui capacidade imunizante a NS3 que se apresenta em contato com a superfície celular ou é secretada. Esta proteína, com sessenta e nove (69) KDa, é uma enzima bifuncional, nucleotídea, trifosfatase/helicase viral. A presença de NS3 estimula a destruição das células infectadas por LT citóxicos. Descrevem-se linfócitos T helper e citotóxicos de pacientes com dengue, apresentando capacidade de reconhecer epitopos de E, NS1 e NS3 ${ }^{(11,12)}$.

A resposta imune celular citotóxica por $\mathrm{LT}$ ocorre sob estímulo das proteínas NS1, NS3 e E dos vírus do dengue ${ }^{(11)}$. Os LT helper atuam na presença das células infectadas com dengue que expressam receptores HLA tipo II, produzindo IFN $\gamma$, IL-2 e o fator estimulador de colônias de macrófagos e granulócitos. Os LT citotóxicos agridem diretamente as células infectadas com dengue, que expressam receptores HLA tipo I, lisando-as ${ }^{(11)}$. Portanto, as células T participam ativamente na resposta imune, reduzindo o número de células infectadas com o vírus, inclusive, conferindo proteção contra reinfecção.

Uma vacina ideal para dengue deveria cumprir as seguintes exigências: promover imunização prolongada contra os quatro (4) tipos de vírus do dengue, não causando o fenômeno de facilitação, por anticorpos, da penetração viral em macrófagos (antibody denpendent enhancement - ADE), que inicia o mecanismo fisiopatológico responsável pelo dengue hemorrágico; ter baixo custo; ter baixa toxidade (principalmente neuro e hepatotoxidade); manter títulos virais no refrigerador ou à temperatura ambiente, durante três (3) dias ${ }^{(13,14)}$. 
Podem-se classificar as vacinas para dengue, já existentes ou em fase de desenvolvimento, $\mathrm{em}^{(6,8,15,16)}$.

\section{Vacinas de vírus vivo atenuado; \\ II. Vacinas de vírus inativados; \\ III. Vacinas de engenharia genética (vacinas recombinantes e vacinas de DNA).}

Para o desenvolvimento das vacinas recombinantes vêm sendo utilizadas as seguintes abordagens:

- Expressão de proteínas de dengue em células eucarióticas;

- Vírus recombinantes;

- Vírus mutantes ou quiméricos;

- Vacinas com vetores vivos.

\section{Vacinas de vírus vivo atenuado}

A atenuação viral consiste em produzir, através de passagens sucessivas de um vírus em células, que não são as de seu hospedeiro natural, uma mutação acidental que reduza sua virulência. As primeiras vacinas de vírus vivo atenuado foram desenvolvidas faz mais de cinqüenta (50) anos, por passagens sucessivas do vírus em cérebro de camundongos, tendo mostrado neurotoxidade. Outra vacina, nos mesmos moldes da de febre amarela 17D, foi buscada através de passagens sucessivas do vírus selvagem em embrião de galinha, entretanto o projeto não progrediu, tendo sido abandonado ${ }^{(8,13)}$.

Na década de setenta (70), primeiramente com o patrocinio do exército dos Estados Unidos, iniciou-se o desenvolvimento de vacinas de dengue, buscando-se atenuação viral por passagens sucessivas do vírus selvagem em cultura de células. Utilizaram-se células de linhagem primária, de rim de cão, e células pulmonares de macacos Rhesus, sabendo-se que as populações de vírus do dengue em uma determinada infecção são geneticamente heterogêneas. Estas células, pertencentes a animais que não são hospedeiros naturais destes vírus, exercem pressão seletiva sobre a população viral, reduzindo a importância de partículas virulentas e permitindo que partículas avirulentas passem a ser dominantes ${ }^{(13)}$. Como critérios iniciais de atenuação viral, buscaram-se vírus que formassem plaques pequenos em culturas de células, que tivessem uma maior sensibilidade a temperatura, produzissem viremia reduzida em macacos e baixa neurovirulência em camundongos, prolongando sua sobrevida. Segundo tais critérios, foram desenvolvidos muitos vírus atenuados, os quais eram pouco imunogênicos ou não produziam a infecção. Entretanto, alguns vírus foram considerados potencialmente aceitáveis para a produção de vacinas ${ }^{(13)}$.
Exemplo destes é o DEN2 PR-159/S-1, com o qual se conseguiu imunizar pacientes, necessitando, entretanto, de imunização simultânea com a vacina de febre amarela. Com a evolução dos estudos para vacinas de dengue, conclui-se que os marcadores in vitro e in vivo, utilizando primatas, não eram ideais e havia necessidade da utilização de voluntários humanos. Finalmente, nos últimos quinze (15) anos, um grupo de pesquisadores, ligado à Universidade de Mahidol, na Tailândia, produziu vírus atenuados e potencialmente imunogênicos contra os quatro (4) tipos de dengue ${ }^{(6,13)}$. Esses vírus foram testados em voluntário humanos, sem infecção prévia por dengue ou outros flavivirus. Testaram-se os vírus, inicialmente, em duplas, depois, em trio, com seroconversão aproximada de $95 \%$ para todos os vírus e, finalmente, em quarteto, com seroconversão de 70 a $80 \%$, em crianças. Raros casos tiveram febre baixa e exantemas, sendo, principalmente, casos com crianças. Também, observou-se que as crianças necessitam de uma menor dose viral para imunização. Concluiu-se, desses estudos, que a vacina quadrivalente é segura e imunogênica. Atualmente, encontra-se em fase de padronização a dose de cada vírus para compor uma vacina de uso em larga escala. Um problema aventado para esta vacina é a questão da reversão da atenuação para virulência, já que alguns dos vírus atenuados, como o dengue tipo 1 , sofreu apenas treze (13) passagens em células de rim de cão ${ }^{(6,13)}$.

Também, estudos vêm analisando a possibilidade de os vírus vacinais atenuados serem disseminados pelo mosquito vetor ${ }^{(14)}$.

\section{Vacinas de vírus inativados}

O desenvolvimento de vacinas de vírus do dengue, inativados, principalmente com formol, esbarra no problema de que esses microorganismos não replicam em altos títulos nos camundongos ou culturas celulares. A necessidade de concentrar os materiais contendo vírus dificulta e encarece muito a produção em massa de vacinas inativadas, razão pela qual esse processo de produção vacinal para dengue foi praticamente abandonado ${ }^{(6,8)}$.

\section{Vacinas de engenharia genética}

\section{- Vacinas recombinantes por expressão de proteí-} nas de dengue em células eucarióticas

Expressão de proteínas de dengue em células eucarióticas foi obtida com Baculovirus recombinantes, contendo a proteína E viral, sem o seu domínio transmembrana. Essa proteína foi expressada em células do inseto Spodoptera frugiperda, que passaram 
a eliminar E sob uma forma solúvel. Observou-se que camundongos imunizados com esta proteína produziam anticorpos neutralizantes e ficavam protegidos da infecção $\mathrm{O}^{(16,17)}$.

\section{- Vacinas com vírus recombinantes}

Para a produção dessas vacinas desenvolveram-se partículas recombinantes, não infectantes, particularmente partículas virais ocas, não contendo RNA. Entretanto, duvida-se de que estas vacinas recombinantes tenham capacidade de estimular imunidade humoral prolongada. A incapacidade de imunização prolongada contraindicaria o uso da vacina, já que a queda dos títulos virais poderia facilitar o fenômeno de ADE, que poderia levar, nos indivíduos em contato com vírus selvagem, ao aparecimento de quadros de dengue hemorrágico. Também, duvida-se de que tais vacinas sejam capazes de estimular a imunidade celular. A dúvida baseia-se nos conhecimentos sobre a forma de processamento e apresentação de antígenos às células imunes. As vacinas recombinantes induziriam mais resposta mediada por LT helper. Os LT citotóxicos não seriam ativados, porque exigem apresentação de antígenos por células infectadas, apresentando MHC classe I. Portanto, não induziriam à imunidade. Entretanto, tem sido descrita a proteção de animais com vacinas recombinantes sem a produção de anticorpos neutralizantes, o que sugere o desenvolvimento, nesses animais, de uma imunidade celular CD4/CD8 - restrita a MHC classe II $^{(16,18,19)}$.

\section{- Vacinas com vírus mutantes e quiméricos}

Vírus do dengue e outros com modificação de genes vêm sendo desenvolvidos. Em alguns estudos, utilizou-se o DNA complementar da cepa de dengue tipo 4, Caribenha, fazendo-se mutações na região 3' não codificadora e no local de clivagem NS1/NS2a. Em outros experimentos, promoveram-se deleções de genes virais, reduzindo a replicação do dengue tipo 4, o que sugeria atenuação viral. Ainda, introduziram-se genes de dengue tipo 1 (C, prM, E) e tipo 2 (Prm e E) após deleção dos genes respectivos do tipo 4, produzindo-se vírus quiméricos. Outras quimeras também vêm sendo desenvolvidas com o vírus da febre amarela vacinal 17D. Também, quimeras promissoras vêm sendo desenvolvidas, utilizando como base o vírus da vacina de dengue tipo 2, tailandesa, PDK53. Trata-se de vírus bem atenuado, que replica bem em células de rim de cachorro, é excelente imunógeno e mostrou-se seguro em experimentos com seres humanos. A estratégia, neste caso, consiste em inserir as regiões codificadoras de prM e E dos vírus dengue tipo1, 3 e 4 no genoma do dengue 2 PDK-53 ${ }^{(16,20)}$.

Um problema importante com esses experimentos é o desconhecimento das mudanças que seriam necessárias para a atenuação daqueles vírus. Atualmente, busca-se conhecer os critérios moleculares que determinam a virulência dos tipos de dengue, permitindo atenuação viral por modificação específica ou troca dos genes ${ }^{(6,8,16)}$.

\section{- Vacinas com vetores vivos}

Vetores vivos para veicularem antígenos de dengue têm sido desenvolvidos com bactérias (salmonella) e vírus, como o da vaccínia, atenuado - NYVAC, o da rubéola, ou adenovírus. O vírus da vaccínia, expressando as proteínas prM e E dos quatro (4) tipos de dengue confere proteção a esses vírus, em camundongos. A capacidade imunogênica da combinação entre os quatro (4) tipos vem sendo testada. Entretanto, um problema com as vacinas de vetores vivos é que a imunidade para dengue depende do número de vetores produzidos pelo organismo, o que pode ser muito variável, dependendo de fatores do hospedeiro, como, por exemplo, uma imunidade prévia contra o vetor ${ }^{(21)}$.

Um problema geral com todas as vacinas recombinantes refere-se às enormes discrepâncias quanto a suas capacidades imunogênicas, e o receio de que produzam uma imunidade de curta duração.

\section{- Vacinas de DNA}

Pretende-se criá-las para dengue, seguindo modelo já utilizado para vírus da encefalite de St. Louis (SLE), pertencente ao mesmo gênero. A estratégia para o preparo dessa vacina consiste em clonar DNA complementar, da região prM e E, dos vírus do dengue em plasmídios, produzir esses genes em grande quantidade, purificar o produto e utilizá-los como imunógenos. Camundongos que receberam os genes de SLE desenvolveram imunidade com uma ou duas (2) imunizações. Essa imunidade, que, acredita-se, deva ser de longa duração, é independente de anticorpos, devendo-se principalmente a linfócitos citotóxicos ${ }^{(8)}$.

Finalmente, deve-se ressaltar, dentre as vacinas citadas, a vacina tailandesa, de vírus do dengue atenuado, como a que apresenta as melhores perspectivas para uma implantação nos próximos três (3) a cinco (5) anos. Essa vacina deverá ser produzida pela Pasteur Merieux Serums and Vaccines Company da França, que adquiriu os direitos em 1993. As vacinas já são produzidas industrialmente de forma monovalente e extensivos testes em laboratório, incluindo neurovirulência 
em macacos, já foram efetuados. Um estabilizador viral, produzido pela empresa, foi misturado às vacinas, com excelentes resultados e permitindo que a vacina possa permanecer até três (3) dias à temperatura ambiente, sem perda significante do título viral. As vacinas, no momento, estão sendo testadas na fase 2, em seres humanos $^{(13)}$. Essas vacinas são as que oferecem melhores perspectivas para uso rotineiro, a médio prazo.

FIGUEIREDO LTM. Dengue vaccines. Medicina, Ribeirão Preto, 32: 21-25, jan./march 1999.

ABSTRACT: The control of dengue is done world-wide by fighting the vector mosquito following the rules preconized by sanitarians of the beginning of the century. The control and the eradication of Aedes aegypti, the principal vector of dengue, is extremely difficult and demand large money investing on personnel, machines, insect poisons and permanent educational campaigns. The best alternative for dengue control is the use of vaccines. In this revision work the research on dengue vaccines is analyzed, including: attenuated viruses; genetic engineering (recombinant vaccines) by virus protein expression in euchariotic cells, recombinant viruses, mutant and chimera viruses, vaccines with living vectors, and DNA vaccines. The attenuated dengue virus vaccines have best chances of a generalized use in the next years.

UNITERMS: Dengue. Vaccines.

\section{REFERÊNCIAS BIBLIOGRÁFICAS}

1 - MONATH TP \& TSAI TF. Flaviviruses. In: RICHMAN DD; WHITLEY RJ \& HAYDEN FG, eds. Clinical virology, Churchill Livingstone, New York, p.1113-1185, 1997.

2 - FIGUEIREDO LTM \& FONSECA BAL. Dengue. In: VERONESI $R$ \& FOCCACIA R, eds. Tratado de infectologia, Atheneu, São Paulo, p.201-214, 1996.

3 - FIGUEIREDO LTM. A febre amarela na Região de Ribeirão Preto durante a virada do século XX: importância científica e repercussões econômicas. Rev Soc Bras Med Trop 29: 63-76, 1996.

4 - GUBLER DJ \& CLARK G. Community-based integrated control of Aedes aegypti: a brief overview of current programs. Am J Trop Med Hyg 50: 50-60, 1994. Suppl.

5 - BRANDT WE. Development of dengue and Japanese encephalitis vaccines. J Infect Dis 162: 577-583, 1990.

6 - MONATH TP, HEINZ F. Flaviviruses. In: FIELDS BN \& KNIPE DM, eds. Virology, 3th ed., Lippincott - Raven, Philadelphia, p. 961-1034, 1996.

7 - CHAMBERS TJ et al. Flavivirus genome organization, expression, and replication. Annu Rev Microbiol 44: 649-688, 1990.

8 - CHAMBERS TJ et al. Vaccine development against dengue and Japanese encephalitis: report of a World Health Organization meeting. Vaccine 15: 1494-1502, 1997.

9 - REY FA et al. The envelope glycoprotein from tick-borne encephalitis virus at 2 A resolution. Nature 375: 291-298, 1995.

10 - CHU MC et al. Genetic relatedness among structural protein genes of dengue 1 virus strains. J Gen Virol 70: 1701-1712, 1989.

11 - KURANE I et al. Dengue virus-specific human CD4'D cytotoxic T-cell clones: Multiple patterns of virus cross reactivity recognize by NS3-specific T cell clones. J Virol 65:1823-1928, 1991.

12 - KURANE I \& ENNIS FE. Immunity and immunopathology in dengue virus infections. Semin Immunol 4: 121-127, 1992.
13 - BHAMARAPRAVATI N \& YOKSAN S. Live attenuated tetravalent dengue vaccine. In: GUBLER DJ \& KUNO G, eds. Dengue and dengue hemorrhagic fever, Cab International, New York, p.367-376, 1997.

14 - KHIN MM et al. Infection, dissemination, transmition and biological attributes of dengue-2 PDK-53 candidate virus vaccine virus after oral infection in Aedes aegypti. Am $\mathbf{J}$ Trop Med Hyg 51: 864-869, 1994.

15 - BRANDT WE. Current approaches to the development of dengue vaccines and related aspects of the molecular biology of flaviviruses. J Infect Dis 157: 1105-1111, 1988.

16 - VENUGOPAL K \& GOULD EA. Towards a new generation of flavivirus vaccines. Vaccine 12: 966-975, 1994.

17 - DEUBEL $V$ et al. Processing, secretion and immunoreactivity of carboxy terminally truncated dengue- 2 envelope proteins expressed in insect cells by recombinant baculovirus. Virology 180: 442-447, 1991

18 - AASKOV JG et al. Failure of dengue 1 sub-unit vaccine to protect mice against a lethal dengue virus infection. Am J Trop Med Hyg 39: 511-518, 1988.

19 - KONISHI E et al. Mice immunized with a subviral particle containing the Japanese encephalitis virus $\mathrm{prM} / \mathrm{M}$ and $\mathrm{E}$ proteins are protected from lethal JEV infection. Virology 188: 714-720, 1992.

20 - BRAY M \& CHING-JUH L. Construction of intertypic chimeric viruses by substitution of structural protein genes. Proc Natl Acad Sci USA 88: 10342-10346, 1991.

21 - FONSECA BA et al. Recombinant vaccinia viruses coexpressing dengue-1 glycoproteins prM and $E$ induce neutralizing antibodies in mice. Vaccine 12: 279-285, 1994.

Recebido para publicação em 23/02/99

Aprovado para publicação em 09/03/99 